\title{
MODEL PROBLEM BASED LEARNING, GUIDED INQUIRY, DAN KEMAMPUAN BERPIKIR KRITIS MATEMATIS
}

\author{
Oktavia Filda Yanti, Rully Charitas Indra Prahmana \\ Universitas Ahmad Dahlan, Jl. Pramuka Kav. 5, Pandeyan, Yogyakarta
}

\begin{abstract}
This research aims to determine differences of mathematical critical thinking skills between students who obtain mathematics learning using Problem Based Learning (PBL) and Guided Inquiry model. The research method used quasi-experimental with matching-only posttest-only control group design which implemented in one of the Junior High School of Yogyakarta. The instrument used is a valid test instrument namely posttest with descriptive evaluation. The result of this research showed that there is a differences of mathematical critical thinking skills between students who obtain mathematics learning using PBL model and students who obtain mathematics learning using guided inquiry model. Furthermore, the average of mathematical critical thinking skills between student who obtain mathematics learning using problem based learning model is higher than students who obtain mathematics learning using guided inquiry model.
\end{abstract}

Keywords: Problem based learning; Guided inquiry; Mathematical critical thinking skills.

\section{PENDAHULUAN}

Berpikir kritis matematis adalah kemampuan intelektual yang dimiliki seseorang untuk memahami permasalahan matematika. Mereka mampu menganalisis permasalahan tersebut, dan dapat memutuskan solusi yang sesuai dari permasalahan tersebut (Haeruman, Rahayu, \& Ambarwati, 2017; Kusdinar, dkk, 2017). Sejalan dengan itu, berpikir kritis matematis juga dapat didefinisikan sebagai kemampuan berpikir logis dan reflektif yang fokus pada cara mengambil keputusan yang dapat dipercaya (Sari, Susiswo, \& Nusantara, 2017; Runisah, Herman, \& Dahlan, 2017). Oleh karena itu, seseorang yang memiliki kemampuan berpikir kritis matematis memiliki kemampuan intelektual dengan berpikir logis dan reflektif dalam memahami permasalahan matematika, menganalisis permasalahan, dan memutuskan solusi yang tepat.

Kemampuan berpikir kritis matematis merupakan kemampuan yang sangat penting (Junaidi, 2017; Liberna, 2015; Jumaisyaroh, Napitupulu, \& Hasratuddin, 2015; Istianah, 2013). Hal itu juga diungkapkan oleh Sumaryati (2013) bahwa menguasai

\begin{tabular}{lr}
\hline Alamat Korespondensi & (2017 Universitas Islam NegeriSunanAmpel Surabaya \\
Email: oktaviafildayanti@gmail.com & e-ISSN 2503 - 1384
\end{tabular}


kemampuan berpikir kritis matematis menjadi penting karena diperlukan untuk menyongsong masa depan yang akan terus berubah. Hal ini sejalan dengan Istianah (2013) yang mengatakan bahwa dengan menguasai kemampuan berpikir kritis matematis, siswa diharapkan mampu memecahkan masalah dalam dunia yang berubah secara terus-menerus. Jadi, kemampuan berpikir kritis matematis memiliki peran penting bagi siswa dalam menyambut masa depan yang terus berubah. Hal tersebut membuat siswa membutuhkan alternatif pilihan yang terbaik dalam menyelesaikan suatu permasalahan.

Siswa membutuhkan kemampuan berpikir kritis matematis ketika dihadapkan pada tantangan dengan mempertimbangkan informasi yang diterima, membuat rencana, menentukan keputusan yang akan diambil, membuat keputusan, dan mengevaluasi (Syarif, 2017). Meskipun kemampuan berpikir kritis matematis sangat dibutuhkan dan penting dimiliki, nyatanya siswa Indonesia belum mampu menguasai kemampuan tersebut dengan baik (Happy \& Widjajanti, 2014). Hal ini senanda dengan Wahyuni, Rahayu, \& Widyati (2017) yang mengatakan bahwa pembelajaran matematika di sekolah menjadi kurang bermakna disebabkan oleh kemampuan berpikir kritis matematis yang kurang dikembangkan oleh siswa. Sehingga, kemampuan berpikir kritis matematis harus dimiliki bahkan dikembangkan oleh siswa sebagai upaya menjadikan pembelajaran matematika yang bermakna di sekolah.

Hasil penelitian menunjukkan bahwa kemampuan berpikir kritis matematis siswa di masih rendah, karena pada proses pembelajaran guru masih menggunakan pembelajaran konvensional (Sari, Susiswo, \& Nusantara, 2017; Kurniati \& Astuti, 2017). Hal ini juga disampaikan oleh Sari, Wahyuni, \& Rosmaiyadi (2016) bahwa kemampuan berpikir kritis matematis siswa cukup rendah. Hal ini sangat mempengaruhi nilai pembelajaran matematika siswa. Oleh karena itu, peneliti mengidentifikasi bahwa kemampuan berpikir kritis matematis siswa perlu ditingkatkan karena berpengaruh terhadap pencapaian tujuan dari pembelajaran di sekolah.

Menurut Fajarwati \& Manoy (2017) bahwa memberikan suatu permasalahan merupakan salah satu upaya yang dapat dilakukan untuk meningkatkan kemampuan berpikir kritis matematis siswa, karena dengan adanya permasalahan mereka akan berusaha berpikir untuk menyelesaikannya dengan mencari solusi dari masalah tersebut. Salah satu model pembelajaran yang dapat meningkatkan kemampuan berpikir kritis 
matematis dalam pembelajaran matematika adalah model pembelajaran problem based learning.

Problem based learning merupakan model pembelajaran yang mempunyai ciri khas karena selalu dimulai dan dipusatkan pada suatu permasalahan (Fatimah, 2012). Sejalan dengan itu, Gunantara, Suarjana, \& Riastini (2014) menyatakan bahwa dalam model problem based learning siswa dilibatkan dalam menyelesaikan permasalahan nyata. Pada penelitian ini, definisi dari model pembelajaran konvensional adalah model pembelajaran yang digunakan oleh guru pada sekolah tersebut yaitu Guided Inquiry. Berdasarkan uraian-uraian di atas, peneliti ingin mengetahui bagaimana perbedaan kemampuan berpikir kritis matematis antara kelompok siswa yang mendapatkan model pembelajaran Problem Based Learning (PBL) dengan siswa yang mendapatkan model pembelajaran Guided Inquiry. Selain itu, untuk mengetahui apakah kemampuan berpikir kritis matematis siswa yang mendapatkan model pembelajaran PBL lebih baik dari pada siswa yang mendapatkan model pembelajaran Guided Inquiry.

\section{METODE PENELITIAN}

Penelitian ini menggunakan pendekatan quasi experimental dengan desain matching-only posttest-only control group design (Fraenkle \& Wallen, 2009). Adapun desain dalam penelitian ini disajikan pada Tabel 1.

Tabel 1. Desain Penelitian

\begin{tabular}{llll}
\hline Kelompok & Subjek & Perlakuan & Tes Akhir \\
\hline Eksperimen & $\mathrm{S}$ & $\mathrm{X}$ & $\mathrm{O}$ \\
Kontrol & $\mathrm{S}$ & $\mathrm{C}$ & $\mathrm{O}$ \\
\hline Keterangan: & X: Problem based learning & C: Guided Inquiry & O: Tes Tertulis
\end{tabular}

Penelitian ini dilaksanakan di SMP Negeri 3 Sewon pada semester 1 (satu) tahun pelajaran 2017/2018. Subjek penelitian adalah siswa kelas IX A dan IX C. Teknik sampling yang digunakan untuk mendapatkan kelompok eksperimen dan kelompok kontrol menggunakan purposive sampling dengan mempertimbangkan kemampuan siswa antara kedua kelas tersebut. Variabel bebas dalam penelitian ini adalah model pembelajaran Problem Based Learning (PBL) dan Guided Inquiry, sedangkan variabel terikatnya adalah kemampuan berpikir kritis matematis siswa. 
Instrumen penelitian yang digunakan dalam penelitian ini berbentuk tes tertulis. Tes tertulis tersebut bertujuan untuk mengetahui kemampuan berpikir kritis matematis setelah pembelajaran dilakukan pada kedua kelas. Tes tertulis berbentuk soal uraian yang terdiri dari 1 soal mudah, 1 soal sedang, dan 1 soal sulit. Sub pokok bahasan yang diujikan adalah menentukan tinggi segitiga menggunakan konsep kesebangunan. Uji validitas instrumen dilakukan secara walk through untuk mengetahui validitas soal baik itu dari segi konten, konstruk, dan bahasa oleh guru pembimbing di sekolah.

Data hasil tes akhir yang telah diperoleh dibuat ke dalam bentuk tabel dan dianalisis menggunakan statistik deskriptif dan uji independent t-test. Uji statistik ini untuk mengetahui perbedaan pengaruh model pembelajaran Problem Based Learning (PBL) dengan model pembelajaran guided inquiry terhadap kemampuan berpikir kritis matematis siswa.

\section{HASIL DAN PEMBAHASAN}

Problem based learning (PBL) adalah salah satu model pembelajaran yang memiliki ciri yaitu mengunakan masalah yang diberikan oleh guru maupun ditemukan oleh siswa itu sendiri (Gunawan, Tegeh, \& Suarjana, 2017). Selanjutnya, siswa dapat memecahkan permasalahan nyata melalui pembelajaran problem based learning (Khotimah, Suhartono, \& Salimi, 2017). Oleh karena itu, dalam proses pembelajaran Problem Based Learning (PBL) siswa dapat diberikan atau menemukan sendiri permasalahan nyata dan mampu memecahan permasalahan tersebut.

Pada proses pembelajaran yang menerapkan model PBL diharapkan siswa secara mandiri dapat memecahkan permasalahan nyata yang akan menghasilkan pembelajaran yang bermakna. Sehingga, siswa menjadi aktif dan antusias dalam proses pembelajaran, namun tetap dalam pengawasan dan bimbingan guru. Aktivitas pembelajaran problem based learning (PBL) dapat dilihat pada Gambar 1. 


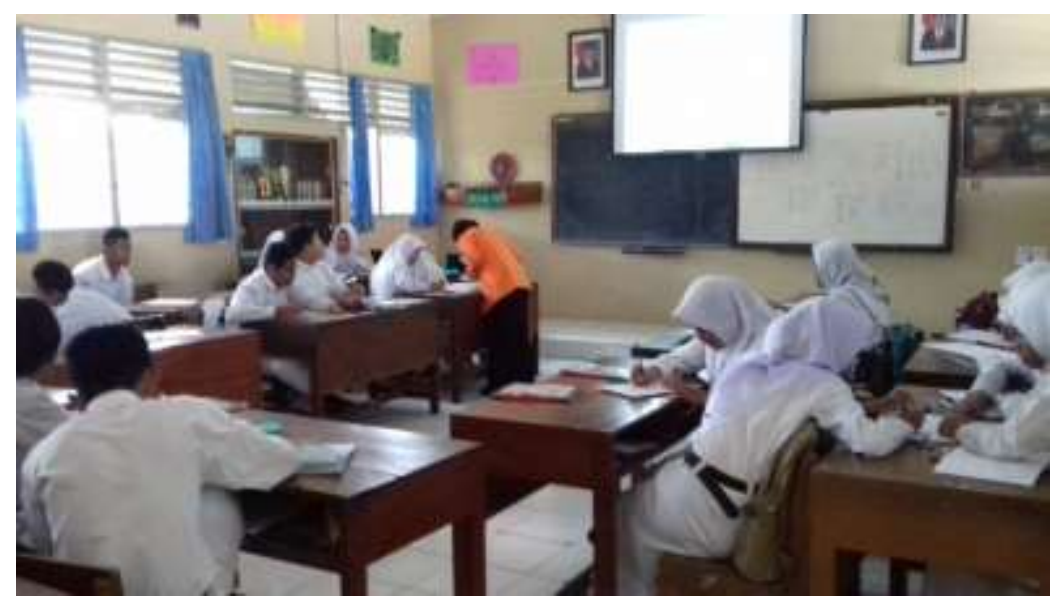

Gambar 1. Aktivitas pembelajaran di kelas eksperimen

Berdasarkan Gambar 1, pembelajaran matematika dengan model pembelajaran problem based learning siswa di kelas terlihat sangat aktif, karena proses pembelajaran diawali dengan guru yang memberikan permasalahan nyata kepada siswa yang terkait dengan materi. Siswa secara mandiri berusaha memecahkan masalah yang diberikan guru. Siswa langsung berlomba-lomba untuk bertanya jika ada kesulitan dalam menyelesaikan permasalahan tersebut. Kemudian, guru sebagai fasilitator selalu berusaha untuk membimbing siswa yang mengalami kesulitan untuk memecahkan masalah tersebut.

Selanjutnya, siswa diberikan soal yang memiliki tingkatan soal mudah berupa konsep-konsep dasar kesebangunan sampai pada soal yang sulit berupa soal pengembangan dari konsep kesebangunan. Dalam menyelesaikan soal, siswa dibimbing oleh guru dengan penjelasan sederhana agar dapat menyelesaikan permasalahan tersebut. Sehingga, hal ini dapat melatih proses berpikir kritis matematis siswa.

Dalam proses pembelajaran yang menggunakan model PBL, guru tidak boleh langsung memberikan konsep, rumus, dan sebagainya. Proses pembelajaran melibatkan siswa menjadi berpikir dengan diberikan masalah, sehingga secara tidak langsung proses pembelajaran yang berbasis pada masalah secara bertahap dapat meningkatkan kemampuan berpikir kritis siswa. Saat proses pembelajaran berlangsung guru berkeliling untuk menjadi fasilitator keilmuan bagi siswa yang mengalami kesulitan dalam memecahkan masalah.

Proses pembelajaran yang menerapkan guided inquiry dapat membuat siswa memahami, memaknai, serta membangun pengetahuan yang baru (Yumiati \& 
Noviyanti, 2017). Sejalan dengan itu Purwatiningsih (2014) mengemukakan bahwa proses guided inquiry menuntut siswa dalam menggunakan ide dan pemahaman yang telah dimiliki sebagai cara untuk menemukan sesuatu yang baru. Oleh karena itu, dalam proses pembelajaran yang menerapkan guided inquiry siswa diajak untuk menemukan pengetahuan baru berdasarkan ide dan pemahaman yang telah dimiliki. Aktivitas pembelajaran guided inquiry disajikan pada Gambar 2.

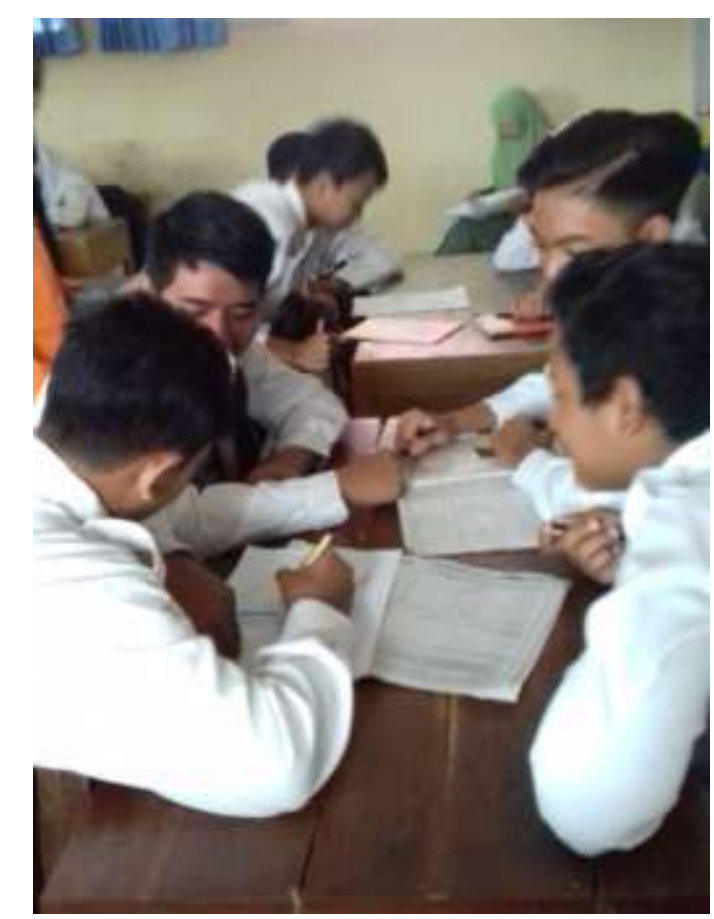

Gambar 2. Aktivitas pembelajaran di kelas kontrol

Berdasarkan Gambar 2, proses pembelajaran yang menerapkan model guided inquiry terlihat melakukan pembelajaran dengan berkelompok. Dalam kelompok siswa diberikan apersepsi berupa pengetahuan sebelumnya sebagai petunjuk untuk membangun pengetahuan baru. Siswa diberikan LKS yang telah tersedia petunjuk pengerjaan dalam menemukan konsep dari kesebangunan. Hal ini dianggap efektif karena masing-masing siswa dalam kelompok tersebut dapat mengemukakan ide yang mereka miliki.

Dalam poses pembelajaran yang menggunakan model guided inquiry guru juga memiliki peran sebagai fasilitator. Guru berkeliling ke masing-masing kelompok untuk melihat bagaimana proses siswa mengemukakan ide, menyampaikan pemahaman yang telah dimiliki, dan bagaimana pengetahuan baru tersebut terbentuk oleh siswa. 


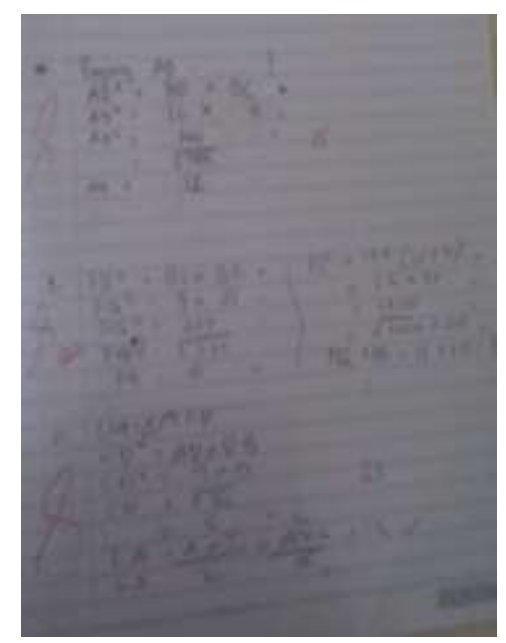

Gambar 3. Salah satu hasil jawaban siswa di kelas eksperimen

Seseorang yang memiliki kemampuan berpikir kritis matematis yaitu memiliki kemampuan intelektual dengan berpikir logis dan reflektif dalam memahami permasalahan matematik, menganalisis permasalahan, dan memutuskan solusi yang tepat. Berdasarkan Gambar 3. Dapat dilihat siswa mengerjakan soal nomor 2 dan nomor 3 dengan baik, untuk soal nomor 2 siswa dapat menghitung panjang PQ + PR yang panjang keduanya belum diketahui. Hal ini menunjukkan bahwa siswa dapat memahami permasalahan matematik.

Pada soal nomor 3, telihat bahwa siswa dapat mencari luas segitiga yang tidak diketahui tingginya, dan proses mencari tinggi segitiga yang dilakukan oleh siswa tersebut dengan menggunakan konsep kesebangunan. Hal ini menunjukkan bahwa siswa dapat menganalisis sebuah permasalahan, dan memutuskan solusi yang tepat dari permasalahan matematik tersebut.

Dalam penelitian ini diperoleh pula data siswa kelas eksperimen dan kelas kontrol yang menggunakan teknik statistik deskriptif. Statistik kedua kelompok disajikan pada Tabel 2.

Tabel 2. Rata-rata hasil tes akhir

\begin{tabular}{lllll}
\hline Kelas & $\mathrm{N}$ & Mean & $\begin{array}{l}\text { Std. } \\
\text { deviation }\end{array}$ & $\begin{array}{l}\text { S.E } \\
\text { Mean }\end{array}$ \\
\hline $\begin{array}{l}\text { Pembelajaran menggunakan } \\
\text { model Problem Based Learning }\end{array}$ & 32 & 76.88 & 17.40 & 3.08 \\
$\begin{array}{l}\text { PBL) } \\
\begin{array}{l}\text { Pembelajaran menggunakan } \\
\text { model Guided Inquiry }\end{array}\end{array}$ & 32 & 66.72 & 15.38 & 2.72 \\
\hline
\end{tabular}


Berdasarkan Tabel 2 rata-rata hasil tes akhir pada kelas yang menerapkan model pembelajaran PBL adalah 76.88, sedangkan rata-rata hasil tes akhir kelas yang menerapkan model pembelajaran guided inquiry adalah 66.72. Jadi, pembelajaran di kelas yang menerapkan model PBL memperoleh rata-rata yang lebih tinggi dibandingkan dengan pembelajaran di kelas yang menggunakan guided inquiry.

Sebelum menganalisis data menggunakan independent t-test, dilakukan uji normalitas dan homogenitas terlebih dahulu. Hasil uji menunjukkan bahwa kelas eksperimen dan kelas kontrol berdistribusi normal dan homogen.

Tabel 3. Hasil analisis statistik parametrik dengan uji independent t-test

\begin{tabular}{ll}
\hline & t-test for Equality of Means (Sig. (2 tailed)) \\
\hline Equal variances assumes & 0.016 \\
Equal variances not assumes & 0.016 \\
\hline
\end{tabular}

Berdasarkan hasil analisis statistik parametrik dengan uji independent t-test, nilai probabilitas yang diperoleh (Sig. 2 tailed) menghasilkan nilai di bawah 0.05 yaitu 0.016 , maka $H_{0}$ ditolak sehingga terdapat perbedaan yang signifikan antara kelas yang memperoleh model pembelajaran problem based learning dengan kelas yang memperoleh model pembelajaran guided inquiry. Hal ini menunjukkan bahwa kemampuan berpikir kritis matematis siswa di kelas yang menerapkan model pembelajaran PBL lebih tinggi dari dibandingkan dengan kelas yang menerapkan model pembelajaran guided inquiry. Hasil ini sejalan dengan penelitian Widodo, dkk (2017) yang terkait kemampuan pemecahan masalah.

\section{SIMPULAN}

Berdasarkan hasil penelitian, terlihat bahwa terdapat perbedaan rata-rata kemampuan berpikir kritis matematis yang signifikan antara siswa yang mendapatkan model pembelajaran problem based learning dengan siswa yang mendapatkan model pembelajaran guided inquiry. Kelompok siswa menggunakan model PBL lebih tinggi dibandingkan dengan kelompok siswa yang menggunakan guided inquiry. 


\section{DAFTAR RUJUKAN}

Fajarwati, H. N., \& Manoy, J. T. (2017). Profil Berpikir Kritis Siswa SMP Dalam Memecahkan Masalah Open-Ended Ditinjau Dari Kemampuan Matematika. MATHEdunesa, 1(6), 105-113.

Fatimah, F. (2012). Kemampuan komunikasi matematis dan pemecahan masalah melalui problem based-learning. Jurnal Penelitian dan Evaluasi Pendidikan, 16(1), 249-259.

Fraenkle, J.R., \& Wallen, N.E. (2009). How to Design and Evaluate Research in Education Seventh Edition. New York: McGraw-Hill.

Gunantara, G., Suarjana, I. M., \& Riastini, P. N. (2014). Penerapan Model Pembelajaran Problem Based Learning untuk Meningkatkan Kemampuan Pemecahan Masalah Matematika Siswa Kelas V. MIMBAR PGSD, 2(1).

Gunawan, I. W. A., Tegeh, I. M., \& Suarjana, I. M. (2017). Pengaruh Model Pembelajaran PBL Berbantuan Media LKS Terhadap Kemampuan Pemecahan Masalah Matematika Siswa Kelas V SD Gugus V Kecamatan Abang. MIMBAR $P G S D, 5(2), 1-10$.

Haeruman, L. D., Rahayu, W., \& Ambarwati, L. (2017). Pengaruh Model Discovery Learning Terhadap Peningkatan Kemampuan Berpikir Kritis Matematis Dan SelfConfidence Ditinjau Dari Kemampuan Awal Matematis Siswa SMA Di Bogor Timur. Jurnal Penelitian Dan Pembelajaran Matematika, 10(2), 157-168.

Happy, N., \& Widjajanti, D. B. (2014). Keefektifan PBL Ditinjau Dari Kemampuan Berpikir Kritis Dan Kreatif Matematis, Serta Self-Esteem Siswa SMP. Jurnal Riset Pendidikan Matematika, 1(1), 48-57.

Istianah, E. (2013). Meningkatkan Kemampuan Berpikir Kritis Dan Kreatif Matematik Dengan Pendekatan Model Eliciting Activities (MEAs) Pada Siswa SMA. Infinity Journal, 2(1), 43-54.

Jumaisyaroh, T., Napitulu, \& Hasratuddin, E. N. (2015). Peningkatan Kemampuan Berpikir Kritis Matematis Dan Kemandirian Belajar Siswa SMP Melalui Pembelajaran Berbasis Masalah. Admathedu, 5(1), 87-106.

Junaidi, J. (2017). Analisis Kemampuan Berpikir Kritis Matematika Siswa Dengan Menggunakan Graded Response Models Di SMA Negeri 1 Sakti. Jurnal Numeracy, 4(1), 14-25.

Khotimah, K., Suhartono, S., \& Salimi, M. (2017). Penerapan Model Problem Based Learning Untuk Meningkatkan Hasil Belajar Matematika Tentang Perkalian Dan Pembagian Pecahan Pada Siswa Kelas V SDN 1 Tamanwinangun Tahun Ajaran 2016/2017. Kalam Cendekia PGSD Kebumen, 5(2.1), 182-186. 
Kurniati, R., \& Astuti, M. (2017). Penerapan Strategi Pembelajaran Open Ended Terhadap Kemampuan Berpikir Kritis Siswa Pada Mata Pelajaran Matematika Kelas V Di Madrasah Ibtidaiyah Negeri 1 Palembang. JIP: Jurnal Ilmiah PGMI, 2(1), 1-18.

Kusdinar, U., Sukestiyarno, Isnarto, \& Istiandaru, A. (2017). Krulik and Rudnik model heuristic strategy in mathematics problem solving. International Journal on Emerging Mathematics Education,1(2), 205-210.

Liberna, H. (2015). Peningkatan Kemampuan Berpikir Kritis Matematis Siswa Melalui Penggunaan Metode Improve Pada Materi Sistem Persamaan Linear DuaVariabel. Formatif: Jurnal Ilmiah Pendidikan MIPA, 2(3), 190-197.

Purwatiningsih, SE. (2014). Penerapan metode penemuan terbimbing untuk meningkatkan hasil belajar siswa pada materi luas permukaan dan volume balok. Jurnal Elektronik Pendidikan Matematika Tadulako, 1(1), 53-63.

Runisah, Herman, T., \& Dahlan, J.A. (2017). Using the 5E learning cycle with metacognitive technique to enhance students' mathematical critical thinking skills. International Journal on Emerging Mathematics Education, 1(1), 87-98.

Sari, A. N., Wahyuni, R., \& Rosmaiyadi, R. (2016). Penerapan Pendekatan Open-Ended untuk Meningkatkan Kemampuan Berpikir Kritis Siswa Pada Materi Aljabar Kelas VIII SMP Negeri 10 Pemangkat. JPMI (Jurnal Pendidikan Matematika Indonesia), 1(1), 20-24.

Sari, M., Susiswo, S., \& Nusantara, T. (2017). Pengembangan LKS Menggunakan Model Problem Creating Untuk Meningkatkan Kemampuan Berpikir Kritis Siswa Kelas VIII SMP. Jurnal Pendidikan: Teori, Penelitian, Dan Pengembangan, 2(6), 773-779.

Sumaryati, E. (2013). Pendekatan Induktif-Deduktif Disertai Strategi Think-PairSquare-Share untuk Meningkatkan Kemampuan Pemahaman Dan Berpikir Kritis Serta Disposisi Matematis Siswa SMA. Infinity Journal, 2(1), 26-42.

Syarif, M. (2017). Pembelajaran Dengan Pendekatan Problem Solving Untuk Meningkatkan Kemampuan Berpikir Kritis Dan Kreatif Matematika Siswa SMA. Jurnal Mutiara Pedagogik, 1(2), 92-101.

Wahyuni, M., Rahayu, W., \& Widyati, R. (2017). Perbandingan Kemampuan Berpikir Kritis Matematis Antara Siswa Yang Belajar Menggunakan Model Problem Based Learning Dan Model Reciprocal Teaching. Jurnal Riset Pembelajaran Matematika Sekolah, 1(1), 37-45.

Widodo, S.A., Purnami, A.S., \& Prahmana, R.C.I. (2017). Team accelerated instruction, initials and problem-solves ability in junior high school. International Journal on Emerging Mathematics Education, 1(2), 193-204. 
Yumiati, Y., \& Noviyanti, M. (2017). Analysis of Mathematic Representation Ability Of Junior High School Students In The Implementation Of Guided Inquiry Learning. Infinity Journal, 6(2), 137-148. 